Reseby, Dr. Quaife, Mr. Guthrie, Mr. W. E. Raymond, and Mr. Hamlet (representing the British Astronomical Association and the Royal Society).

Prof. Moors, introducing our two parties, remarked that the Australian expedition, which was going to Vavau to observe the eclipse, expected to learn a great deal from us. After Mr. Hamlet's reference to the voyage of Captain Cook in 1770, when he sailed to the South Seas to observe the transit of Venus, and also to the British and Commonwealth expeditions on the present occasion, the Lord Mayor heartily wished all the expeditions success, and instanced the voyages of Sir Ernest. Shackleton and Captain Percy Scott as showing what could be gained to science by close study under arduous conditions.

Prof. Pollock expressed the hope that the advent of the present British parties would benefit the scientific workers in Australia and raise and sustain that enthusiasm without which no good work was ever accomplished. Father Cortie replied in an appropriate manner, pointing out that Britishers felt quite at home in Australia, and that such expeditions helped to cement further, if necessary, the friendship between Australia and the Mother Country.

In my reply I laid particular stress on the importance of the occasion for furthering the proposal for a Solar Physics Observatory for Australia. I pointed out the importance of filling up the gap of longitude between Kodaikánal (India) and Mount Wilson Observatory (U.S.A.), and that in Australia the weather conditions were ideal for a large observatory of this kind. I also indicated the important part played by the sun in controlling our terrestrial atmospheric movements, and that a close study of the sun was of first importance to Austrafians, whose population was so largely composed of those who reaped benefit from the soil. After this pleasing ceremony was over we adjourned to another room to drink the health of the King.

In the afternoon we all went to Coccatoo Island to call on Captain Colomb, the ship being still in dry dock. He greeted us very heartily, and at his request we gave him an account of our programme and requirements.

In the evening we all attended a meeting of the British Astronomical Association, and at its conclusion $\mathrm{Mr}$. McClean, Mr. Anderson, and I went with Mr. Raymond to the observatory to see the show clusters, nebulæ, and double stars of the southern hemisphere.

The following morning was occupied in tallying all the eclipse cases from the Otway. These were to be transferred to H.M.S. Encounter by steam lighter on Monday, March 20. During the afternoon I boarded the Encounter to give Captain Colomb detailed information about the assistance required. I suggested to him the importance of communicating with England as soon as possible after the eclipse in order to inform the home authorities of our results. This he took in hand, and it was arranged that H.M.S. Encounter should send a wireless message to H.M.S. Pioneer at Auckland, which would be transmitted through to England by cable.

The next day (Sunday, March 19) we all went out by steamer to the beautiful River View Jesuit College, where Father Cortie and Brother. McKeon were staying. The rector and the fathers received us in a most hospitable manner. The college is situated away up towards the beautiful harbour of Port Jackson, and is an imposing structure amongst lovely scenery. Since our arrival in Sydney it had been very hot, and the damp atmosphere had made our various duties rather laborious; even the Australians considered it so. The steam to River View was delightful in the extreme, and we were able to gain some idea of the great future such an important port must have. There is very deep water everywhere, and the largest ships can lie alongside any of the innumerable harbours. At River View the very beautiful seismographs, which are in the charge of the distinguished worker Father Pigot, were shown to us. Every detail of these instruments and their functions were carefully pointed out.

The next day (March 20), at an early hour, the steam lighter was alongside the wharf, and $\mathrm{Mr}$. McClean and I went and superintended the placing of the cases in the lighter. Then we steamed away, and with the help of the Encounter's crew got all the cases safely stowed away in torpedo flats and other available spots.

NO. 2 I 69, vol. 86]
This morning I had expected Mr. Hunt to arrive from Melbourne, as I had been requested by the Hon. King O'Malley, the Minister for Home Affairs, through $\mathrm{Mr}$. Hunt, to visit and report on the proposed site for the Solar Physics Observatory near the new Federal Capital site, and Mr. Hunt was to escort me there and back. $\mathrm{Mr}$. Baracci had arranged to proceed to the site from Melbourne, and we were all to meet there. At midday I met Mr. Hunt, and he proposed that we should start the same evening, to which I consented. In the meantime, Mr. Hunt took me to call on Mr. Stephen Mills, the Collector of Customs, who is the successor to Colonel Lockyer (now retired); the latter I met in Melbourne a few days ago. Colonel Lockyer had very kindly given me two letters, one for Father Cortie, which would clear us of any difficulty that might arise in relation to custom duties. These proved very useful, and saved us much anxiety.

W. J. S. LOCKYER.

(To be continued.)

\section{THE WORK OF THE ROYAL GEOGRAPHICAL} SOCIETY.

$\mathrm{N}$ looking to the future, it is important to inquire how 1 the society will be able to maintain its reputation and its usefulness in the new conditions of geographical knowledge. It is true that the South Pole is as yet uncaptured, that the map of Arabia is still largely composed of great blank spaces, and that the bend of the Brahmaputra is drawn by guesswork in our atlases. But all these problems will, it is probable, be solved before long, and where then will be the field in which the explorer may hope to win renown by robbing the unknown of its romance? We must sooner or later face the fact that the work by which this society has become best known in the past represents an almost finished chapter in geographica history, and we should sometimes, in preparation for the future, ask ourselves what ought to be our rôle when the last leaf in that chapter has actually been turned.

When endeavouring thus to take time by the forelock, we should perhaps in the first place inquire more precisely as to the nature of the change which is now taking place and as to how soon it is likely to be accomplished. Systematic surveys are, we know, being pressed forward in many parts of the world, of which until recently the maps were produced mainly by the efforts of enthusiastic amateurs, whilst now they are turned out with almost machine-like regularity and precision by Government officials. As to the British Empire, the annual reports of the Colonial Survey Committee show how rapid has been the advance in this direction, and what satisfactory progress has been made, though in certain localities the authorities, in spite of past experience, seem disposed to linger on in a state of comparative topographical ignorance. Outside the British Empire similar changes are taking place, though less rapidly, with the result that when the international map of the world on the scale of I : $1,000,000$ is completed, as it will be before many years have passed, a large proportion of it will be hased on surveys sufficiently accurate to ensure the work holding good for many a century to come, except for the rise of new towns and the alteration in political boundaries. But in spite of all this progress there are likely to remain vast tracts of land, mapped in a fashion, no doubt, but with the details inaccurate and incomplete, where for at least half a century or more from this date the independent traveller will find ample opportunities of adding to the knowledge of the earth we live in. Indeed, for some years to come large areas are likely to exist our knowledge of which can only be increased at the risk of the traveller's life. But although the available topographical information concerning many regions will for long remain very imperfect, yet it is inevitable that the day will come when the whole world will be mapped with fair accuracy, and to that condition of things this society will have to adapt itself.

Nearly all great changes, however, take place gradually, the process of evolution being, as a rule, an advance

1 Extracts from tha address of the president, Mainr Leonard Darwin, at the anniversary meeting of the Royal Geographical Society, May 22. 
made by a great number of small steps; and no sudden geographical revolution need be feared. To move with the times ought not to be very difficult, therefore, and to do so it is mainly necessary to look to the immediate future, or to take "short views of things," to use the words of that wise man Sydney Smith. If this policy be steadily pursued, there need be no cause for alarm for many years to come, at all events; for, as already suggested, plenty of geographical work yet remains to be done. We ought no doubt, in view of the changing conditions, to direct our efforts with more persistence than heretofore in the direction of encouraging travellers to make systematic and detailed examinations of comparatively small areas, and not merely to cover long distances with the result of doing little more than confirm the impressions of previous explorers. Their surveys should be as good as is possible in the circumstances, and the information they collect should be extensive, varied, systematic, and recorded with reference to the needs of the students of science and history, as well as of the man of commerce. In short, the traveller of the future ought to be a trained topographer, or to have thoroughly prepared himself in advance for some definite class of investigation.

As regards internal administration, the aim must be to make the society's house a place where accurate information can readily be obtained concerning all countries, including our own, the information thus supplied being all that could be described as geographical within the most elastic meaning of the word. The acquisition of suitable maps and books should, indeed, in future only be limited by financial necessity, whilst the collection of geographical photographs should be well maintained. No pains should be spared to make our systems of indexes as perfect as possible, a subject to which, as a fact, considerable attention has recently been paid; and with such aids the staff should be in a position to give every assistance to all students wishing to utilise the vast stores of information which the premises should contain. In short, we shall want more maps, more books, more photographs, and a more convenient house to hold both them and the steadily accumulating objects of interest which we own; and if the society continues to grow in usefulness on the lines suggested, we must look forward to the possibility of a material increase being needed in the number of the staff. Moreover, our means of keeping touch with foreign countries should be considered from time to time, to see if they are not capable of improvement. For example, as a single possible suggestion, might it not be worth considering whether British consuls, whilst actually serving abroad, should not be allowed to join our ranks with some special advantages as regards fees? Then, again, partly with the same object of facilitating the supply of information to our fellows, partly with the view of making our collections more generally useful, and partly in order to disarm the criticism made against us of wishing to poach on the preserves of other sciences, it might perhaps be well to allow the fellows of certain other learned societies to use our libraries with the same freedom with which they can now consult the maps in our map room.

As to the work of exploration and investigation for which we are not directly responsible, this should, as heretofore, continue to receive our warmest encouragement and our help when possible.

One other function which this society may always usefully perform, and one which has thus far been too much neglected. Science is cosmopolitan, and certainly the records of this society's proceedings during recent years, where the names of Sven Hedin, Peary, Charcôt, and many other distinguished foreign explorers so prominently appear, prove that this aspect of our duties is not now being overlooked. It is not, however, as it seems to me, in the least inconsistent with a belief in our world-wide obligations to hold that the work done by our fellowcountrymen has an especial claim on our attention, and that one of the aims of a national geographical society should be to keep alive the knowledge of the great deeds of British explorers in the past. Is it not probable that the history of Australia and New Zealand would have taken a very different turn if the work actually done by Captain Cook had been forestalled by some explorer owing nothing to these isles? And yet to that great man no NO. 2 I69, VOL. 86$]$ fitting monument has yet been erected. As to Africa, its map should have the names of our fellow-countrymen written all over it if intended to indicate the historical development of that continent-a development due in large measure to British exploration, the history of which we should never allow to die. In the case of thousands of adventurers who set forth to America and elsewhere from these islands in times gone by, and to whose exertions is fargely due the fact that English is now the most widely known language on the face of the earth, and that these islands hold in relation to their size an absolutely unique place in the history of the world, it is true that of these men we do not even know their names, though the effect of their exertions yet surrounds us on every side. It is to be hoped, therefore, that there will always exist in this land a body of men banded together with the object, amongst others, of making more widely known what was done by British explorers in the past, and of honouring the heroic spirit of these unnamed thousands which drove them forth to face untold dangers, and thus to help to build that Empire of which we are so proud.

\section{ORGANISATION AND PROGRESS IN ECONOMIC BIOLOGY.}

DURING the past decade economic biology has slowly but surely taken a definite place in our system of sciences in this country, and although at present but a sturdy infant, it would seem that it is destined to play no mean part in stimulating research and experimentation in the near future.

We have, fortunately, outgrown the prejudice that has for many years clung to practical science, and on all sides we can see investigations taking place of deep and farreaching scientific interest, but at the same time fraught with great import to man and his multifarious activities.

Once men begin to think and work along certain definite lines, it is not unnatural that they should seek to associate together, in order to discuss their methods of work, and the latest results obtained by their investigations. Without such association much unnecessary duplication of worl occurs, and the lack of organisation retards otherwise legitimate progress.

The foundation of the Association of Economic Biologists in November, 1904, was the outward expression of a feeling such as this that had long been simmering in the minds of economic biologists in the British Isles, and on the occasion of the tenth general meeting, which has recently been held at the University of Birmingham, where the first meeting took place, it seems not unnatural that we should pause and reffect upon the organisation and progress of this special branch of biological science.

During the life of the above association, meetings have been held at the universities of Birmingham, Liverpool, Cambridge, Edinburgh, Oxford, and Manchester, and one each at the Imperial Institute and University College, London. In looking at the list of papers read at these meetings, one cannot fail to be struck at the large amount of original work that has been carried out by the members, much of which has been published and adequately illustrated. The problems discussed relate to almost every subject wherein the economic biologist can aid or assist the physician, veterinarian, agriculturist, horticulturist, stock breeder, fruit grower, forester, fisherman, manufacturer, \&c. Since 1904 the members of this association have contributed in no small degree to the general advance that has been made in this particular science.

With progress and increased interest the workers also increase, and it is significant that at the last two meetings questions relating to organisation have figured prominently in the programmes. Few will forget Prof. Hickson's admirable address delivered last year at Manchester, on the place of economic zoology in a modern university, or the discussion that followed, both clearly indicating how fully it was realised that a sound scientific training was the best preparation for future specialisation.

In a more restricted sense, Mr. H. Maxwell Lefroy dealt with the training of economic entomologists at the last meeting. Mr. Lefroy has had a long and unique experience of the kind of men that are required in our colonies, but so far he has failed in his efforts to obtain such from 